\title{
Nursing diagnoses in women deprived of freedom
}

\author{
Diagnósticos de enfermagem em mulheres privadas de liberdade
}

Izabelle de Freitas Ferreira ${ }^{1}$, Tatiane Gomes Guedes ${ }^{2}$, Sheila Coelho Ramalho Vasconcelos Morais ${ }^{2}$, José Cristovam Martins Vieira², Marcelle Guimarães de Mello³, Francisca Márcia Pereira Linhares²

Objective: to analyze the nursing diagnoses profile of women deprived of freedom, using the International Classification for Nursing ${ }^{\circledR}$ Practice version 1.0. Methods: a descriptive study, conducted with 186 women deprived of freedom. Nursing Diagnoses were extrapolated based on the clinical data of the participants, collected through a structured form and clinical reasoning. Results: there were 44 nursing diagnostic statements, among the most common, there were: infection risk (70.9\%); fluid intake, decreased (61.2\%); Sleep, impaired (60.7\%); tobacco abuse, started (51.6\%); health seeking behavior, committed (50.0\%). Conclusion: the diagnoses are related to factors that compromise the biopsychosocial health. The nurse, health staff member in the prison setting, must recognize and assess the individual and collective needs of women deprived of freedom. The inference of nursing diagnoses, based on clinical reasoning, contributes to a humanized, empathic and special care.

Descriptors: Nursing Diagnosis; Nurse; Prisons, Women's Health.

Objetivo: analisar o perfil dos diagnósticos de enfermagem de mulheres privadas de liberdade, utilizando a Classificação Internacional para a Prática de Enfermagem ${ }^{\circledR}$ versão 1.0. Métodos: estudo descritivo, realizado com 186 mulheres privadas de liberdade. Os Diagnósticos de Enfermagem foram inferidos baseados nos dados clínicos das participantes, coletados por meio de um formulário estruturado e no raciocínio clínico. Resultados: foram identificadas 44 declarações diagnósticas de enfermagem, entre as mais frequentes: Risco de infecção (70,9\%); Ingestão de líquidos, diminuída (61,2\%); Sono, prejudicado (60,7\%); Abuso de fumo, iniciado (51,6\%); Comportamento de busca de saúde, comprometido (50,0\%). Conclusão: os diagnósticos estão relacionados a fatores que comprometem a saúde biopsicossocial. 0 enfermeiro, membro da equipe de saúde no cenário prisional, deve reconhecer e avaliar as necessidades individuais e coletivas de mulheres privadas de liberdade. A inferência dos diagnósticos de enfermagem, pautada no raciocínio clínico, contribui com o cuidado humanizado, empático e diferenciado.

Descritores: Diagnóstico de Enfermagem; Enfermeiro; Prisões; Saúde da Mulher.

\footnotetext{
${ }^{1}$ Hospital Metropolitano Norte Miguel Arraes. Recife, PE, Brazil.

${ }^{2}$ Universidade Federal de Pernambuco. Recife, PE, Brazil.

${ }^{3}$ Instituto Federal de Pernambuco. Recife, PE, Brazil.
} 


\section{Introduction}

Brazil is currently the fourth country with the largest prison population in the world ${ }^{(1)}$. Between 2000-2014, the female prison population in Brazil increased 567.4\%. The largest female prison population growth from 2007 to 2014 is the federal units of Alagoas (444.0\%), Rio de Janeiro (271.0\%), Sergipe (184.0\%). Pernambuco in the absolute number over the same period, occupying the first place in the country's northeast region, with 12,485 women deprived of freedom ${ }^{(2)}$.

Overcrowding is a reality in Brazilian prisons. Also, the precarious conditions of food and hygiene, leisure and overblown drug use, make prisons a space of human degradation and disease ${ }^{(3)}$.

Brazil has legal strategies to ensure health in the prison environment. Ordinance No. 177 of 2003 provides for the National Health Plan for the Prison System, introduces the nurse as health team member, and aims to reduce injuries and damage caused by the confinement conditions with a specific health policy for deprived of freedom ${ }^{(4)}$.

The nurse, under Resolution 358/2009 of the Federal Nursing Council, which deals with the systematization of nursingcareand theimplementation of the Nursing Process in public or private settings in which nursing care is, shall perform all the steps of the process of the deliberate and systematic way. It is a tool that organizes, directs and enhances the quality of care, bringing the individual holistically visibility and enabling the informed actions in critical and reflective knowledge. The Nursing Process, in turn, guides the nurse for assistance guided by the patient assessment, developed in five stages (nursing history or collecting nursing data, nursing diagnosis, nursing planning, implementation and nursing assessment) ${ }^{(5)}$.

In this study, the nursing diagnoses are highlighted, a necessary step for the care planning that will enable decision making for the actions or interventions, aiming to achieve the expected results, identifying the problems and the risks involved.
For the development of nursing diagnoses, nurses need to take ownership of a common language that promotes understanding among the team. They need to use a diagnostic classification that allows naming the nursing phenomena. Considering the need to use a standardized language, the International Classification for Nursing Practice (ICNP ${ }^{\circledR}$ ) is a unifying framework for all rating systems.

To formulate diagnoses and nursing results, the International Council of Nurses, based on the ISO 18104 standard calls for the mandatory use of a term shaft focus and a term of Judgment axis, may be increased by terms of other axes, as need elucidation of the concept of the statement ${ }^{(6)}$.

From the above, it is asked: what are the nursing diagnoses in women deprived of freedom?

The objective to answer this question was to analyze the profile of nursing diagnoses of women deprived of freedom, using the ICNP ${ }^{\circledR}$ Version $1.0^{(7)}$.

\section{Methods}

Descriptive study conducted in Colônia Penal Feminina from Recife, Pernambuco, Brazil from June 2012 to July 2013. During this period, the general population of the unit was 630 women deprived of freedom. Based on the calculation of finite population, the sample consisted of 186 women.

The women were randomly selected by penitentiary agents, considering the restricted access to the pavilions to officials of the institutions. They excluded those not allowed to leave the cell because they represent a risk.

For data collection, an instrument was used, previously tested, consisting of variables which included identification, socioeconomic and demographic data, lifestyle, current complaints, personal medical and family history, physical examination and sexual and reproductive aspects. It was applied in an individual meeting in days and predetermined times. Each interview lasted on average 40 minutes. 
Initially, it was built a list of all the problems arising from the variables related to the current complaints with life habits, with personal medical history with physical examination and sexual and reproductive aspects to compose the diagnosis. Subsequently, the problems were grouped in converged data and conducted a clinical trial to select the descriptor focus axis and judgment axis (nursing diagnosis) that represents the identified medical condition. To seek the convergence of data, two researchers participated in the diagnostic inference process.

In total, there were 44 diagnostic statements. The five most prevalent for the study were considered, to prioritizing diagnoses for setting goals and nursing behaviors directed to the public studied.

Data from the socioeconomic and demographic profile were analyzed descriptively in the software Statistical Package for the Social Sciences version 17.0, with a $95 \%$ confidence interval and subsequently the nursing diagnoses.

The study complied with the formal requirements contained in the national and international standards of regulatory research involving human beings.

\section{Results}

Among the 186 women deprived of freedom, 71 (38.2\%) were between 18 and 25 years old, 91 (48.9\%) were married, 163 being with children, 114 (61.3\%) of mixed skin, 111 (59.7\%) had incomplete primary education, 33 (17.7\%) were housewives, 70 (37.7\%) Catholic. The origin of most of them (135; $72.7 \%$ ) came from the metropolitan area of Recife, $99(53.2 \%)$ were held for less than six months, 44 (23.7\%) between 6 and 12 months in prison.

Of diagnostic statements, there was more prevalent nursing diagnoses and clinical data for each diagnosis, with a higher incidence of the infection risk (10010104), 132 (70.9\%); fluid intake (10008015) decreased, 114 (61.2\%); Sleep, impaired (10012929),
113 (60.7\%); tobacco abuse, starting (10022247) 96 (51.6\%); and health seeking behavior (10008782) committed, 93 (50.0\%) of participants (Table 1$)$.

Table 1 - More frequent nursing diagnoses in women deprived of freedom, according to ICNP $®$ Version 1.0

\begin{tabular}{lcl}
\hline Nursing Diagnoses & $\mathbf{n}(\%)$ & \multicolumn{1}{c}{ Clinical records } \\
\hline Risk of infection $132(70.9)$ & $\begin{array}{l}\text { Sharing of non-sterile materials; sexual } \\
\text { practices without protection; unhealthy } \\
\text { environment }\end{array}$ \\
Fluid intake decreased $114(61.2)$ & $\begin{array}{l}\text { Low water consumption } \\
\text { Insomnia; difficulty falling asleep; } \\
\text { environmental stressors; absence of } \\
\text { anxiolytic medications; anxieties and } \\
\text { personal concerns }\end{array}$ \\
Changed sleep pattern $113(60.7$ \\
$\begin{array}{l}\text { Tobacco uses start/ } 96(51.6) \\
\text { increased }\end{array}$ & $\begin{array}{l}\text { Active smoking starting and/or increased } \\
\text { practice in the institution }\end{array}$ \\
$\begin{array}{l}\text { Health seeking behav- } 93(50.0) \\
\text { ior compromised }\end{array}$ & $\begin{array}{l}\text { Distancing practices and routines for the } \\
\text { prevention of diseases }\end{array}$ \\
\hline
\end{tabular}

\section{Discussion}

Nursing care guided in the nursing process provides opportunities to women deprived of liberty, assistance that values not only biological but also psychosocial issues. In this sense, knowing the profile of nursing diagnosis gives opportunity planning directed to the real needs of this population.

The characteristics of women deprived of freedom are similar to other surveys conducted in women's prisons, that is young, single women with low levels of education and different social classes by the lack of opportunities ${ }^{(8-9)}$.

When assessing the profile of women incarcerated, it is imperative to consider the factors that contribute to the entry into the world of crime. There is a context of inequality in Brazilian society, marked above all by unemployment and lack of access to education, health and leisure, which differs from fundamental rights envisaged in the Constitution. Such disparities point to the close relationship of the neglect of social rights with the early entry of women in crime.

The literary productions in the prison context are reduced, especially the listed nursing care and its 
implications for individuals in situations of deprivation of liberty, damaging the wide contrast data ${ }^{(10)}$.

In the diagnosis "Risk of infection (10010104)", the term "infection" means a disease process characterized by expression of pathogenic microorganisms to the body reproduce and multiply, causing diseases by local cellular injury, release of toxins or antigen-reaction antibody ${ }^{(7)}$. Associating the word "infection" to the term "risk" of the judgement axis, it was evaluated that women with permanent tattoos made by unauthorized people and nondisposable materials within the prison unit and the history of sexual practice, most of the time with more than one partner without a condom, constituted the factors rich for infection.

The presence of the risk of infection is enhanced by the prison situation and vulnerability of these women. Reported situations, by the study participants, as overcrowding in the cells with little air circulation, plus the everyday use of toilets without proper hygienic conditions, are essential factors for the spread of respiratory diseases and skin diseases ${ }^{(4)}$.

The various infectious diseases of high morbidity are natural consequences of the complexity of confinement, the harmful environment, inadequate nutrition, the problem of the low number of trained professionals and the slowness of the system. Consequently, falling ill in prisons is the anticipated judgment of the many internal people ${ }^{(11)}$.

The Executive Penal Law No. 7210 of 1984 provides the appropriate size of cells for a given number of people, aiming at maintaining the prison population salubrious environment. However, crowded cells with improper sanitation are observed and thus exposed health population to risks.

The analysis of social health policies focused on the prison population, shows constitutionally guaranteed the right to health, but there is still much to be done for the realization of this right ${ }^{(12)}$.

The nursing diagnosis, "fluid intake (10008015) decreased" is defined as fluid intake to obtain the water needed for growth, operation, and maintenance of life ${ }^{(7)}$. The inference of this diagnosis is justified by reports of inmates as the poor quality of water supplied to the prison unit, this complaint also common in another prison unit ${ }^{(13)}$.

The recommended is an intake from 2.0 to 3.0 liters of water per day. However, habituation subjects reported to the intake only, on average, $500 \mathrm{ml}$ per day. It is known that the benefits of adequate water consumption represent the prevention of diseases as renal lithiasis, urinary tract infection in women and the development of polycystic kidney disease ${ }^{(14)}$.

The lack and poor quality of water are a reality found in the national panorama of prison units, increasing precariousness of hygiene and unsanitary $^{(15)}$. The decree No. 2914 of 2011 of the Ministry of Health requires the control of water quality distributed collectively for human consumption. It determines that all water, essential for the maintenance of human life, has potable standards. It is up to the competent bodies, whether at the federal, state or municipal level, ensuring compliance with the determinations laid this regulation.

The diagnosis "impaired sleep (10012929)" is understood as the regular decrease in body activity with reduced levels of consciousness, metabolism and sensitivity, although reversible to external stimuli(7). Women reported waking up several times at night, difficulty falling asleep and insomnia for several days. Some of the interviewees confirmed fatigue and daytime sleepiness.

It was evident that the sleep disorders in these women occur by exposure to some intrinsic factors of the institution: the precarious accommodation in the cells, insufficient and inadequate mattresses, excessive noise and difficult access to anxiolytic medications.

Anxiety, doubts about the progress of the trial proceedings, concern for the family and the absence of the children were observed as sleep disturbing, reflecting indirectly and directly on the quality of the home. These aspects are relevant to the clinical reasoning of the nursing diagnosis "Sleep, impaired". Also, at night the women are idle, with restricted 
activities, so thoughts that hitherto were camouflaged, especially those that had some activity during the day.

Fear, sadness, future uncertainties, anxiety, leisure and environmental discomfort are references recognized by women of another prison, as aspects of sufferings of prison routine. The study confirms that the inmates have committed mental health and that the sum of factors only hinders the execution of the sentence $^{(16)}$.

It was found that anxiety and routine concerns are influencers in poor quality sleep, reflected in a few hours of sleep, malaise, fatigue and excessive daytime sleepiness the next day ${ }^{(17)}$.

Smoking is something notorious in the prison unit, most of those who declared themselves smokers make up a daily consumption around twenty cigarettes, which corresponds to a complete portfolio, which explains the presence of diagnosis "Tobacco use start/increased (10019766)".

More than five million deaths annually are estimated due to the use of cigarettes, and the tendency of smokers practice continues, that number can exceed eight million annual deaths by 2030 , and there are still estimated around 600 deaths annually among individuals exposed to cigarette smoke. These data is a concern, given the excessive agglomeration in the cells and little air circulation, thus hindering the spread of airborne substances ${ }^{(18)}$.

Vale salientar que o fumo está associado à mortalidade de várias doenças, dentre elas: câncer (pulmão, boca, faringe, laringe, esôfago, estômago, pâncreas, bexiga, rim, colo do útero e leucemia mieloide aguda), doença pulmonar obstrutiva crônica, doença coronariana, hipertensão arterial e acidente vascular encefálico $^{(18)}$.

It is worth noting that smoking is associated with mortality from various diseases, such as cancer (lung, mouth, pharynx, larynx, esophagus, stomach, pancreas, bladder, kidney, cervix, and acute myeloid leukemia), chronic obstructive pulmonary disease, coronary heart disease, hypertension and stroke ${ }^{(18)}$.
Therefore, efforts are necessary to offer to women deprived of freedom social support for the reduction of smoking in the prison institutions, combating truancy and other issues related to tobacco use. The leisure, access to school and work activities are strategies that in addition to promoting the rehabilitation can contribute to the reduction of tobacco use in the interim.

The "Health seeking behavior committed (10008782)" is a self-management activity with specific characteristics. Regarded as a predictable way of health care management, perspectives related to acceptable ways to request and obtain assistance from others $^{(7)}$. The shaft judgment, the inadequate term was understood by the account of non-habituation of examinations prevention of breast cancer and cervical cancer, as well as the non-realization of selfexamination of the breasts, mammography and Pap test (test Pap smear of the cervix).

Some of the participants reported never having done any screening test, and the reporting of having sex with multiple partners without using condoms.

Even though they know the risk of numerous diseases, some of the interviewees showed little interest and concern with some preventive measures, such as the practice of safe sex and the performance of the Pap test. They justified not holding examinations for shame, especially the need for a position, which is essential for speculum examination. Moreover, some reported having carried out the examination but did not return to service to get the result for fear of discovering an abnormality, especially cancer.

Women who attended the nursing consultation to perform the screening test for the first time, bring similar testimony to the views of women in this study who reported the feeling of fear or loss, shame, embarrassment and the erroneous idea of not need the frequency of tests. Another aggravating factor refers to the difficulty of access to public health services as one of the obstacles to the non-performance of preventive examinations $^{(19)}$. 
Thus, nurses, health team member professional of the prison system should collaborate in an attempt to alleviate the problems related to the diagnosis "health seeking behavior committed" here evidenced by performing activities, guided by the understanding of the vulnerabilities that are inserted women in seclusion situation, for the prevention, either through specific tests such as the Pap smear or educational activities, such as the performance of the breast selfexamination ${ }^{(20)}$.

\section{Conclusion}

It is observed that nursing diagnoses are related to numerous risk factors that compromise the biopsychosocial health of women deprived of freedom, reality found, in general, in Brazilian prisons.

In this perspective, the nurse active in the prison setting must recognize and assess the individual and collective needs of women deprived of liberty. Therefore, the inference of nursing diagnoses, based on clinical reasoning, contributes humanized, empathic and special care. Care that transcends the mistakes made by people in deprivation of liberty, such as women represented here.

\section{Collaborations}

Ferreira IF, Linhares FMP, Guedes TG, Morais SCRV, Melo MG and Vieira JCM contributed in the design and project design, data collection and analysis, writing and critical analysis of the article and the final approval of the version to be published.

\section{References}

1. Ministério da Justiça (BR). Departamento Penitenciário Nacional. Levantamento Nacional de Informações Penitenciárias INFOPEN - junho de 2014 [Internet]. 2014 [citado 2015 jun 13]. Disponível em: http://www.justica.gov.br/seusdireitos/politica-penal
2. Ministério da Justiça (BR). Departamento Penitenciário Nacional. Levantamento Nacional de Informações Penitenciárias INFOPEN Mulheres - junho de 2014. [Internet]. 2014 [citado 2015 jun 13]. Disponível em: http://www12.senado.leg.br/ noticias/arquivos/2016/03/14/apresentacaodetalhada-do-infopen-mulheres

3. Nicolau AIO, Ribeiro SG, Lessa PRA, Monte AS, Nascimento RC, Ferreira RCN, et al. A picture of the socioeconomic and sexual reality of women prisoners. Acta Paul Enferm. 2012; 25(3):386-92.

4. Ministério da Saúde (BR). Secretaria de Atenção à Saúde. Departamento de Ações Programáticas Estratégicas. Plano Nacional de Saúde no Sistema Penitenciário. Brasília: Ministério da Saúde; 2005.

5. Medeiros AL, Santos SR, Cabral RWL. Sistematização da assistência de enfermagem na perspectiva dos enfermeiros: uma abordagem metodológica na teoria fundamentada. Rev Gaúcha Enferm. 2012; 33(3):174-81.

6. Silva AF, Nóbrega MML, Macedo WCM. Diagnósticos/resultados de enfermagem para parturientes e puérperas utilizando a Classificação Internacional para Prática de Enfermagem. Rev Eletr Enferm [periódico na Internet]. 2012 [citado 2015 ago 27]; 14(2):267-76. Disponível em: https://www.fen.ufg.br/fen_revista/v14/n2/ v14n2a06.htm

7. Garcia TR. Classificação Internacional para a Prática de Enfermagem-CIPE®: aplicação à realidade brasileira. Porto Alegre: Artmed; 2015.

8. Canazaro D, Argimon IIL. Características, sintomas depressivos e fatores associados em mulheres encarceradas no Estado do Rio Grande do Sul, Brasil. Cad Saúde Pública. 2010; 26(7):1323-33.

9. D'Eça Junior A, Cunha SF, Costa MR, Sousa VEC, Soares DL, Mochel EG. Câncer cérvico uterino: estudo com mulheres em cárcere. Rev Enferm UFPE online [periódico na Internet]. 2011 [citado 2015 ago 27]; 5(9):2175-81. Disponível em: http://www.revista.ufpe.br/revistaenfermagem/ index.php/revista/article/view/1880/pdf_687

10. Santos MNA, Sá AMM. The carrier-being of tuberculosis in prisons: a nursing study. Esc Anna Nery. 2014; 18(2):350-5. 
11. Reis CB, Bernardes EB. O que acontece atrás das grades: estratégias de prevenção desenvolvidas nas delegacias civis contra HIV/AIDS e outras doenças sexualmente transmissíveis. Ciênc Saúde Coletiva. 2011; 16(7):3331-8.

12. Lermen HS, Gil SDC, Jesus LO. Saúde no cárcere: análise das políticas sociais de saúde voltadas à população prisional brasileira. Physis Rev Saúde Coletiva. 2015; 25(3):905-24.

13. Kölling GJ. O necessário olhar fraterno para o que está desumanizado: a saúde no sistema prisional. Rev Criminol Ciênc Penitenciárias [periódico na Internet]. 2014 [citado 2015 ago 27]; 4(1). Disponível em: http://www.procrim.org/revista/ index.php/COPEN/article/view/313/433

14. Romão Júnior JE. Água e a saúde do rim transplantado. Rev Bras Med [periódico na Internet]. 2013 [citado 2015 ago 27]; 70(n.esp.). Disponível em: http://pesquisa.bvsalud.org/ portal/resource/pt/lil-704853

15. Mendes APT. Sistema prisional e direitos humanos. Escola de Direito do Rio de Janeiro da Fundação Getulio Vargas. [Internet]. 2015 [citado 2016 jan 13]. Disponível em: https://bibliotecadigital.fgv. $\mathrm{br} / \mathrm{dspace} / \mathrm{bitstream} / \mathrm{handle} / 10438 / 15008 /$ Cadernos\%20FGV\%20DIREITO\%20RIO\%20 -\%20S\%C3\%A 9rie \% 20 Cl\%C3\%ADnicas $\% 20$ -20Volume\%204.pdf?sequence=1\&isAllowed=y
16. Lima GMB, Pereira Neto AF, Amarante PDC, Dias MD, Ferreira Filha MO. Mulheres no cárcere: significados e práticas cotidianas de enfrentamento com ênfase na resiliência. Saúde Debate. 2013; 37(98):446-56.

17. Pereira ECA, Schmitt ACB, Cardoso MRA, Pereira WMP, Lorenzi-Filho G, Blumel JE, et al. Prevalence of excessive daytime sleepiness and associated factors in women aged 35-49 years from the "Pindamonhangaba Health Project" (PROSAPIN). Rev Assoc Med Bras. 2012; 58(4):447-52.

18. Instituto Nacional de Câncer (INCA). Organização Pan-Americana da Saúde. Pesquisa especial de tabagismo - PETab: relatório Brasil. Rio de Janeiro: INCA; 2011.

19. Ferreira MLSM. Motivos que influenciam a não realização do exame de Papanicolau segundo a percepção de mulheres. Esc Anna Nery. 2009; 13 (2):378-84.

20. Oliveira AC, Pessoa RS, Carvalho AMC, Magalhães RLB. Risk and protection factors for women's health in the prevention of cervical cancer. Rev Rene. 2014; 15(2):240-8. 